\title{
EFEKTIVITAS PEMBERIAN MADU DAN PISANG AMBON TERHADAP ANEMIA PADA MAHASISWI PROGRAM STUDI DIPLOMA III KEBIDANAN STIKES YPIB MAJALENGKA
}

\author{
${ }^{1}$ Ayu Idaningsih, ${ }^{2}$ Siti Purnama Mustikasari \\ ${ }^{1,2}$ Sekolah Tinggi Ilmu Kesehatan YPIB Majalengka \\ ayuidaningsih2011@gmail.com
}

\begin{abstract}
Abstrak
Anemia pada remaja merupakan masalah utama yang terjadi di seluruh dunia. Salah satu penanganan non farmakologis anemia dengan pemberian madu dan pisang ambon. Berdasarkan hasil studi pendahuluan sebanyak 3 dari 6 orang mahasiswi mengalami anemia ringan. Penelitian ini bertujuan untuk mengetahui efektivitas pemberian madu dan pisang ambon terhadap anemia pada mahasiswi Program Studi D III Kebidanan STIKes YPIB Majalengka tahun 2020. Jenis penelitian yang digunakan pre eksperimen dengan desain one group pretest-posttest design. Populasinya seluruh mahasiswa tingkat I dan II Prodi D III Kebidanan STIKes YPIB Majalengka sebanyak 54 orang dan sampelnya sebanyak 15 orang dengan teknik purposive sampling dilakukan bulan April-Juni 2020. Pengumpulan data menggunakan lembar observasi. Analisis univariat menggunakan distribusi tendensi sentral dan analisis bivariatnya menggunakan uji t berpasangan. Hasil penelitian menunjukkan bahwa ratarata kadar hemoglobin pada mahasiswi sebelum pemberian madu dan pisang ambon sebesar 11,45 gr\% dan sesudah pemberian madu dan pisang ambon sebesar 12,15 gr\%. Pemberian madu dan pisang ambon efektif terhadap anemia pada mahasiswi Prodi Diploma III Kebidanan STIKes YPIB Majalengka tahun $2020(\rho=0,000)$. Kesimpulan pemberian madu dan pisang ambon efektif terhadap anemia pada mahasiswi Program Studi Diploma III Kebidanan STIKes YPIB Majalengka tahun 2020.
\end{abstract}

Kata Kunci $\quad$ :Madu, Pisang Ambon, Anemia

\section{Pendahuluan}

Kesehatan yang paling utama pada masa remaja adalah kesehatan reproduksi.
Masa remaja merupakan proses perjalanan hidup dari masa anak-anak yang terbebas oleh tanggung jawab sampai pada masa 
JOURNAL OF MIDWIFERY CARE :

VOL. 01 NO. 01, DESEMBER 2020

DOI : $10.34305 / j m c . v 1 i 1.189$
Ciptaan disebarluaskan di bawah

Lisensi Creative Commons Atribusi-

NonKomersial-Berbagi Serupa 4.0

Internasional. dewasa yang memiliki berbagai tanggung jawab (Manuaba, 2015). Secara umum remaja dibagi menjadi tiga fase batasan umur yaitu fase remaja awal dalam rentang usia dari 12-15 tahun, fase remaja madya dalam rentang usia 15-18 tahun dan fase remaja akhir dalam rentang usia 18-21 tahun (Sarwono, 2015).

Masa remaja dalam proses perjalanan hidup manusia sangat penting untuk diperhatikan karena pada masa remaja ini terjadi proses awal kematangan organ reproduksi yang ditandai dengan adanya peristiwa menstruasi pada remaja putri. Hal ini dapat menyebabkan penurunan kadar besi dalam darah atau anemia (Kusmiran, 2016).

Anemia pada remaja merupakan masalah utama yang terjadi di seluruh dunia. Menurut WHO, (2018) prevalensi anemia pada remaja putri di dunia berkisar $40-88 \%$. Angka kejadian anemia pada remaja putri di negara-negara berkembang sekitar 53,7\% dari semua remaja putri, anemia sering menyerang remaja putri disebabkan karena keadaan stress, haid, atau terlambat makanan (WHO, 2018).

Prevalensi anemia pada remaja putri di Indonesia pada tahun 2018, yaitu pada kelompok remaja usia 11-14 tahun sebesar 13,5\% dan usia 15-21 tahun sebesar 29,5\%
(Kementerian Kesehatan RI, 2019). Angka kejadian anemia pada kelompok remaja di Provinsi Jawa Barat pada tahun 2018 mencapai $41,5 \%$. Anemia pada remaja putri di Kabupaten Majalengka masih merupakan masalah kesehatan masyarakat karena prevalensinya lebih dari 15\%. Angka kejadian anemia di Kabupaten Majalengka tahun 2018 didapatkan anemia pada balita umur 0-5 tahun sebesar 40,5\%, usia remaja sebesar 26,5\%, Wanita Usia Subur (WUS) sebesar 39,5\%, pada ibu hamil sebesar 43,5\% (Dinas Kesehatan Provinsi Jawa Barat, 2019).

Anemia merupakan keadaan menurunnya kadar hemoglobin ( $\mathrm{Hb})$, hematokrit, dan jumlah sel darah merah di bawah nilai normal. Hemoglobin adalah metaloprotein (protein yang mengandung zat besi) di dalam sel darah merah yang berfungsi sebagai pengangkut oksigen dari paru-paru ke seluruh tubuh (Arisman, 2017). Remaja dinyatakan anemia jika kadar hemoglobinnya di bawah ambang batas normal yaitu jika < 12gr\% (Yuni, 2015).

Anemia pada remaja perlu ditangani secara tepat karena jika tidak mendapatkan penanganan akan berdampak buruk bagi kesehatan. Dampak dari anemia mungkin tidak dapat langsung terlihat, tetapi dapat berlangsung lama dan mempengaruhi 
JOURNAL OF MIDWIFERY CARE :

VOL. 01 NO. 01, DESEMBER 2020

DOI : $10.34305 / j m c . v 1 i 1.189$
Ciptaan disebarluaskan di bawah

Lisensi Creative Commons Atribusi-

NonKomersial-Berbagi Serupa 4.0

Internasional. kehidupan remaja selanjutnya. Anemia pada remaja dapat berdampak panjang untuk dirinya dan juga untuk anak yang ia lahirkan kelak. Dampak dari anemia bagi remaja diantaranya adalah terganggunya pertumbuhan dan perkembangan, kelelahan, meningkatkan kerentanan terhadap infeksi karena sistem kekebalan tubuh yang menurun, menurunkan fungsi dan daya tahan tubuh, lebih rentan terhadap keracunan dan terganggunya fungsi kognitif (Kusmiran, 2016).

Beberapa jenis anemia dapat sebabkan karena defisiensi zat besi, infeksi atau gangguan genetik, yang paling sering terjadi adalah anemia yang disebabkan oleh kekurangan asupan zat besi. Kehilangan darah yang cukup banyak, seperti saat menstruasi, kecelakaan dan donor darah berlebihan juga dapat menghilangkan zat besi dalam tubuh. Wanita yang mengalami menstruasi setiap bulan berisiko menderita anemia. Kehilangan darah secara perlahanlahan di dalam tubuh, seperti ulserasi polip kolon dan kanker kolon juga dapat menyebabkan anemia (Briawan, 2017).

Salah satu penanganan yang dapat dilakukan oleh remaja untuk mengatasi anemia adalah dengan pemberian madu dan pisang ambon. Madu mengandung zat besi yang sangat diperlukan dalam pembentukan hemoglobin. Zat besi berperan sangat penting dalam pembentukan hemoglobin, kebutuhan zat besi dalam tubuh $65 \%$ dibutuhkan untuk pembentukan hemoglobin. Hemoglobin yaitu molekul protein yang mengandung zat besi dan merupakan pigmen darah yang membuat darah berwarna merah (Kusmiran, 2016).

Kandungan besi dalam 100 gram madu terdapat kandungan besi sebesar 0,42 mg. Disamping itu juga madu mengandung enzim-enzim seperti diastase, glukosa oksidase, katalase serta vitamin A, vitamin B dan betakaroten. Selain itu juga dilengkapi mineral berupa kalium magnesium, fosfor, tembaga, mangan, natrium dan kalsium. Bahkan terdapat hidrogen peroksida yang dihasilkan oleh glukosa oksidase dan inhibin (Hudri, 2017).

Pada kasus anemia ringan, madu telah terbukti mampu meningkatkan kadar hb, jika dikonsumsi selama 7 hari berturutturut sebanyak 28 gr/hari (Islamiyah, 2017). Menurut Adji, (2017) madu sebaiknya dikonsumsi sebanyak setengah sendok makan dan di minum setiap sehari setiap pagi dan sore untuk menjaga kesehatan termasuk mengatasi kelelahan akibat anemia.

Penanganan anemia juga dapat dilakukan dengan pemberian buah pisang 
JOURNAL OF MIDWIFERY CARE :

VOL. 01 NO. 01, DESEMBER 2020

DOI : $10.34305 / j m c . v 1 i 1.189$
Ciptaan disebarluaskan di bawah

Lisensi Creative Commons Atribusi-

NonKomersial-Berbagi Serupa 4.0

Internasional. ambon. Buah pisang memiliki kandungan zat besi yang cukup tinggi sehingga cocok untuk penderita anemia. Mengkonsumsi 2 buah pisang setiap selama 7 hari dapat mengatasi kekurangan sel darah merah atau anemia. Dalam 100 gram pisang mengandung zat besi sebanyak 1,60 mg (Wardhany, 2016). Menurut Almatsier, (2015); Maesaroh \& Fauziah, (2016) mengatakan jika mengkonsumsi pisang ambon 2 kali sehari secara teratur dapat meningkatkan jumlah sel darah merah, dimakan sebaiknya pagi dan sore hari.

Hasil penelitian yang dilakukan Muslihah, (2017) pada mahasiswi STIKes Bogor Husada menunjukkan bahwa kadar hemoglobin pada kelompok yang mengkonsumsi pisang ambon dengan madu mengalami kenaikan sebesar $0,8 \%$. Sedangkan Rustiani, (2016) di Akademi Keperawatan Pemkab Subang Dalam penelitiannya menyatakan bahwa kandungan pisang dan madu yang kaya dengan zat-zat pembentuk sel darah merah seperti zat besi (Fe) mampu meningkatkan hemoglobin dan menghambat terjadinya anemia pada remaja putri. Penelitian Islamiyah, (2017) pada remaja yang mengalami anemia di SMAN 1 Sumedang setelah diberi perlakuan pisang dan madu selama 7 hari sebanyak 28 gr/hari dan dikonsumsi pada pagi hari terbukti dapat meningkatkan kadar $\mathrm{Hb}$.

Hasil studi pendahuluan yang dilakukan di Program Studi Diploma III Kebidanan STIKes YPIB Majalengka pada tanggal 17 Januari 2020 terhadap 6 orang terdiri dari 3 mahasiswi tingkat I dan 3 mahasiswi tingkat II. Hasil studi diperoleh informasi bahwa hasil pengukuran kadar $\mathrm{Hb}$ dengan $\mathrm{Hb}$ sahli sebanyak 3 orang $(50 \%)$ mengalami anemia ringan (11,0-11,9 gr\%) dan 3 orang (50\%) normal (12-14 gr\%). Juga diperoleh informasi bahwa dari 3 orang yang mengalami anemia tersebut mengatakan selama ini tidak melakukan pengobatan karena dianggap hal biasa.

Berdasarkan uraian tersebut, maka penulis tertarik untuk melakukan penelitian dengan judul "Efektivitas Pemberian Madu dan Pisang Ambon Terhadap Anemia Pada Mahasiswi Program Studi Diploma III Kebidanan STIKes YPIB Majalengka Tahun 2020”.

\section{Metode}

Jenis penelitian yang digunakan adalah pre eksperimen dengan desain one group pretest-posttest design. Populasinya seluruh mahasiswa tingkat I dan II Program Studi Diploma III Kebidanan STIKes YPIB Majalengka sebanyak 54 orang dan 
JOURNAL OF MIDWIFERY CARE :

VOL. 01 NO. 01, DESEMBER 2020

DOI : $10.34305 / j m c . v 1 i 1.189$
Ciptaan disebarluaskan di bawah

Lisensi Creative Commons Atribusi-

NonKomersial-Berbagi Serupa 4.0

Internasional. sampelnya sebanyak 15 orang dengan teknik purposive sampling dilakukan pada bulan April-Juni tahun 2020. Pengumpulan datanya menggunakan lembar observasi.
Analisis univariat menggunakan distribusi tendensi sentral dan analisis bivariatnya menggunakan uji t berpasangan.

\section{Hasil}

\section{Analisis Univariat}

Tabel 4.1 Distribusi Anemia sebelum Pemberian Madu dan Pisang Ambon

\begin{tabular}{ccccc}
\hline Anemia pada Mahasiswi & $\begin{array}{c}\text { Mean } \\
\text { Median }\end{array}$ & S.D & Minimal-Maksimal & $\mathbf{9 5 \%}$ CI \\
\hline $\begin{array}{c}\text { Kadar Hb Sebelum } \\
\text { pemberian madu dan pisang } \\
\text { ambon }\end{array}$ & 11,45 & 0,269 & $11,0-11,9$ & $11,30-11,60$ \\
\hline
\end{tabular}

Berdasarkan tabel 4.1, menunjukkan bahwa kadar $\mathrm{Hb}$ pada mahasiswa sebelum pemberian madu dan pisang ambon rataratanya 11,45 gr\%, dengan median $11,5 \%$ gr\% dan nilai standar deviasinya 0,269. Kadar $\mathrm{Hb}$ paling rendah adalah 11,0 gr\% dan paling tinggi adalah 11,9 gr\%. Berdasarkan nilai 95\%CI, artinya 95\% diyakini bahwa kadar hemoglobin sebelum pemberian madu dan pisang ambon pada mahasiswi Program Studi Diploma III Kebidanan STIKes YPIB Majalengka tahun 2020 berada di antara 11,30-11,60 gr\%.

Tabel 4.2 Distribusi Anemia Sesudah Pemberian Madu dan Pisang Ambon

\begin{tabular}{ccccc}
\hline Anemia pada Mahasiswi & $\begin{array}{c}\text { Mean } \\
\text { Median }\end{array}$ & S.D & $\begin{array}{c}\text { Minimal- } \\
\text { Maksimal }\end{array}$ & 95\% CI \\
\hline $\begin{array}{c}\text { Kadar Hb sesudah pemberian madu } \\
\text { dan pisang ambon }\end{array}$ & $\begin{array}{c}12,15 \\
12,10\end{array}$ & 0,456 & $11,5-13,0$ & $11,90-12,40$ \\
\hline
\end{tabular}

Berdasarkan tabel 4.2, menunjukkan bahwa kadar $\mathrm{Hb}$ pada mahasiswa sesudah pemberian madu dan pisang ambon rataratanya $12,15 \mathrm{gr} \%$, dengan median $12,10 \%$ gr\% dan nilai standar deviasinya 0,456. Kadar $\mathrm{Hb}$ paling rendah adalah 11,5 gr\% dan paling tinggi adalah 13,0 gr\%. Berdasarkan nilai 95\%CI, artinya 95\% diyakini bahwa kadar hemoglobin sebelum pemberian madu dan pisang ambon pada mahasiswi Program Studi Diploma III Kebidanan STIKes YPIB Majalengka tahun 2020 berada di antara 11,90-12,40 gr\%. 


\section{Analisis Bivariat}

Efektifitas Pemberian Madu dan Pisang Ambon terhadap Anemia

Tabel 4.3 Efektifitas Pemberian Madu dan Pisang Ambon terhadap Anemia

\begin{tabular}{ccccccc}
\hline Anemia pada mahasiswi & Mean & Beda mean & N & Std. Dev & T & P value \\
\hline Kadar hb (pretest) & 11.45 & 0,7 & 15 & 0.2669 & & 0,000 \\
Kadar hb (posttest) & 12.15 & & & 0.4565 & -4.740 & \\
\hline
\end{tabular}

Berdasarkan tabel 4.3, menunjukkan bahwa rata-rata kadar hemoglobin pada mahasiswi yang anemia sebelum pemberian madu dan pisang ambon adalah 11,45 gr\% sedangkan sesudah pemberian madu dan pisang ambon adalah 12,15\%, sehingga terdapat kenaikan sebesar 0,7 gr\%. Hasil uji $\mathrm{t}$ berpasangan pada $\alpha=0,05$ diperoleh nilai $\mathrm{p}=0,000$ yang berarti $\mathrm{p}$ value $<\alpha$, sehingga dengan demikian maka pemberian madu dan pisang ambon efektifitas terhadap anemia pada mahasiswi Program Studi Diploma III Kebidanan STIKes YPIB Majalengka tahun 2020.

\section{Pembahasan}

\section{Gambaran Anemia Sebelum Pemberian}

\section{Madu dan Pisang Ambon}

Berdasarkan hasil penelitian, menunjukkan bahwa rata-rata kadar hemoglobin pada mahasiswi sebelum pemberian madu dan pisang ambon sebesar $11,45 \mathrm{gr} \%$. Mahasiswi yang mengalami anemia dapat dikarenakan umumnya mahasiswa yang tinggal di kos cara makannya tidak teratur sehingga peluang kekurangan zat besi cukup besar, akibatnya mahasiswi akan mudah lelah, mengantuk, pusing, dan daya konsentrasinya akan menurun atau mengalami anemia. Masih banyaknya masyarakat yang mengalami anemia dikarenakan salah satunya karena faktor kekurangan asupan zat besi yang diperlukan dalam tubuh.

Hasil penelitian ini sedikit lebih tinggi dibanding dengan penelitian Suprayitno, (2017) di Kecamatan Cidahu Kabupaten Kuningan menunjukkan bahwa sebelum perlakuan rata-rata kadar hemoglobin pada remaja putri yaitu 11,3 gr\% dan juga lebih tinggi dibanding dengan hasil penelitian Muslihah, (2017) di STIKes Bogor Husada menunjukkan bahwa rata-rata kadar hemoglobin sebelum perlakuan adalah $11,2 \%$.

Anemia pada remaja merupakan masalah gizi pada remaja putri. Anemia gizi disebabkan oleh kekurangan zat gizi yang 
JOURNAL OF MIDWIFERY CARE :

VOL. 01 NO. 01, DESEMBER 2020

DOI : $10.34305 / j m c . v 1 i 1.189$
Ciptaan disebarluaskan di bawah

Lisensi Creative Commons Atribusi-

NonKomersial-Berbagi Serupa 4.0

Internasional. berperan dalam pembentukan hemoglobin, dapat karena kekurangan konsumsi atau gangguan absorpsi (Almatsier, 2015). Anemia pada remaja merupakan keadaan remaja ditandai menurunnya kadar hemoglobin, hematokrit, dan jumlah sel darah merah di bawah nilai normal (Arisman, 2017).

Anemia pada mahasiswi sebelum pemberian madu dan pisang ambon sebesar $11,45 \mathrm{gr} \%$ termasuk anemia ringan. Hal ini sesuai dengan batasan WHO dalam Yuni, (2015) bahwa kadar hemoglobin pada remaja diklasifikasikan menjadi anemia ringan jika kadar hemoglobin 11 gr\% - 11,9 gr\%, anemia sedang jika kadar hemoglobin 8 gr\% - 10,9 gr\% dan berat jika kadar hemoglobin< 8 gr\%.

Dampak dari anemia mungkin tidak dapat langsung terlihat, tetapi dapat berlangsung lama dan mempengaruhi kehidupan remaja selanjutnya. Anemia pada remaja perempuan dapat berdampak panjang untuk dirinya dan juga untuk anak yang ia lahirkan kelak. Dampak dari anemia bagi remaja diantaranya adalah terganggunya pertumbuhan dan perkembangan, kelelahan, meningkatkan kerentanan terhadap infeksi karena sistem kekebalan tubuh yang menurun, menurunkan fungsi dan daya tahan tubuh, lebih rentan terhadap keracunan dan terganggunya fungsi kognitif (Kusmiran, 2016).

Pada penelitian ini rata-rata kadar hemoglobin pada mahasiswa Program Studi Diploma III Kebidanan STIKes YPIB Majalengka tahun 2020 termasuk kategori ringan yaitu sebesar 11,45 gr\%. Maka dari itu, perlunya pihak kampus untuk memberikan kuliah baik secara teori maupun praktik kepada mahasiswi tentang pencegahan dan penanganan anemia pada remaja sehingga mahasiwi Program Studi Diploma III Kebidanan dapat mengatasi anemianya secara mandiri. Bagi mahasiswi agar meningkatkan pengetahuan dan keterampilan tentang pencegahan dan penanganan anemia secara aktif dengan mengakses informasi dari berbagai media.

\section{Gambaran Anemia Sesudah Pemberian} Madu dan Pisang Ambon

Berdasarkan hasil penelitian, menunjukkan bahwa rata-rata kadar hemoglobin pada mahasiswi Program Studi Diploma III Kebidanan STIKes YPIB Majalengka tahun 2020 sesudah pemberian madu dan pisang ambon sebesar 12,15 gr\%. Kadar hemoglobin mahasiswi sesudah pemberian madu dan pisang ambon selama seminggu ternyata dapat meningkat dan kembali normal, disamping karena kondisi libur yang panjang mahasiswa tinggal 
JOURNAL OF MIDWIFERY CARE :

VOL. 01 NO. 01, DESEMBER 2020

DOI : $10.34305 / j m c . v 1 i 1.189$
Ciptaan disebarluaskan di bawah

Lisensi Creative Commons Atribusi-

NonKomersial-Berbagi Serupa 4.0

Internasional. bersama orang tua dan cara makannya sudah mulai baik juga karena adanya pemberian madu dan pisang ambon secara teratur setiap hari selama seminggu pada pagi dan sore hari sehingga kandungan zat besi dalam pisang ambon dan madu dapat meningkatkan kadar hemoglobinnya menjadi normal.

Hasil penelitian ini lebih rendah dibanding hasil penelitian Rustiani, (2016) di Akademi Keperawatan Pemkab Subang menyimpulkan bahwa setelah diberi pisang dan madu menjadi 12,7 gr\% dan juga lebih rendah dibanding dengan hasil penelitian Mahardika \& Zuraida, (2016) pada mahasiswi STIKes Abdi Nusantara Bekasi" menyimpulkan bahwa kadar hemoglobin mahasiswi setelah diberi perlakuan selama seminggu menjadi $12,4 \%$.

Pencegahan dan penanganan anemia pada remaja menurut Almatsier, (2015) dapat dilakukan dengan meningkatkan konsumsi makanan bergizi, diantaranya makan makanan yang banyak mengandung zat besi dari bahan makanan hewani (daging, ikan, ayam, hati, telur) dan bahan makanan nabati (sayuran berwarna hijau tua, kacangkacangan, tempe). Juga bisa dengan makan sayur-sayuran dan buah-buahan yang banyak mengandung vitamin C (daun katuk, daun singkong, bayam, jambu, tomat, jeruk, dan nanas) sangat bermanfaat untuk meningkatkan penyerapan zat besi dalam usus.

Buah pisang dan ambon mengandung zat besi dan jika dikonsumsi dengan teratur akan membantu pembentukan kadar hemoglobin. Sehingga seseorang yang mengalami anemia dapat diatasi dengan mengkonsumsi buah pisang dan ambon. Buah pisang memiliki kandungan zat besi yang cukup tinggi sehingga cocok untuk penderita anemia. Mengkonsumsi 2 buah pisang setiap harinya secara rutin. Manfaat buah pisang untuk mengatasi kekurangan sel darah merah atau anemia. Sedangkan madu mengandung zat besi yang mana zat besi sangat diperlukan dalam pembentukan hemoglobin. Zat besi berperan sangat penting dalam pembentukan hemoglobin, kebutuhan zat besi dalam tubuh $65 \%$ dibutuhkan untuk pembentukan hemoglobin. Sebagaimana kita ketahui, dalam sel darah merah terdapat hemoglobin (Hb) yaitu molekul protein yang mengandung zat besi dan merupakan pigmen darah yang membuat darah berwarna merah. Zat besi merupakan komponen yang sangat penting dari hemoglobin (Kusmiran, 2016).

Pada penelitian ini, kadar hemoglobin pada mahasiswi Program Studi 
JOURNAL OF MIDWIFERY CARE :

VOL. 01 NO. 01, DESEMBER 2020

DOI : $10.34305 / j m c . v 1 i 1.189$
Ciptaan disebarluaskan di bawah

Lisensi Creative Commons Atribusi-

NonKomersial-Berbagi Serupa 4.0

Internasional.
Diploma III Kebidanan STIKes YPIB Majalengka tahun 2020 menjadi normal. Maka dari itu pihak kampus disamping memberikan kuliah secara teori dan praktik pada mahasiswi tentang pencegahan dan penanganan anemia dengan alternatif buah pisang dan ambon, juga perlu mengoptimalkan kegiatan seminar di lingkungan kampus tentang masalah anemia pada remaja. Bagi mahasiswi agar aktif mengikuti seminar mengenai masalah anemia pada remaja, sehingga mahasiswi dapat melakukan pencegahan dan penanganan dengan tepat ketika mengalami anemia.

\section{Efektivitas Pemberian Madu dan Pisang} Ambon terhadap Anemia

Berdasarkan hasil penelitian, menunjukkan bahwa pemberian madu dan pisang ambon efektif terhadap anemia pada mahasiswi Program Studi Diploma III Kebidanan STIKes YPIB Majalengka tahun 2020. Juga diperoleh besarnya peningkatan kadar hemoglobin setelah diberi madu dan pisang ambon sebesar 0,7 gr\%. Adanya pengaruh hal ini karena pisang ambon dan madu mengandung unsur besi yang sangat dibutuhkan dalam pembentukan hemoglobin sehingga dengan mengkonsumsi secara teratur akan meningkatkan kadar hemoglobin secara efektif.
Hasil penelitian ini sejalan dengan hasil penelitian Islamiyah, (2017) di SMAN 1 Sumedang menunjukkan bahwa terdapat pengaruh pisang dan madu terhadap kadar hemoglobin remaja putri yang mengalami anemia dan besarnya peningkatan sebesar $1,6 \%$. Juga sejalan dengan hasil penelitian Cholifah \& Wulandari, (2018) pada remaja putri yang mengalami anemia menunjukkan ada perbedaan pemberian madu terhadap kenaikan kadar $\mathrm{Hb}$ antara kelompok intervensi dan kelompok kontrol sesudah diberikan perlakuan (nilai $\rangle=0,000$ ). Demikian juga dengan penelitian Muslihah, (2017) di STIKes Bogor Husada menunjukkan bahwa pemberian buah pisang ambon dengan madu efektif dalam meningkatkan kadar hemoglobin mahasiswi anemia dan kenaikan kadar hemoglobin setelah pemberian buah pisang ambon dengan madu sebesar $0,8 \%$.

Hasil penelitian ini sejalan dengan teori bahwa salah satu penanganan yang dapat dilakukan oleh remaja untuk mengatasi anemia adalah dengan pemberian madu dan pisang ambon. Madu mengandung zat besi yang sangat diperlukan dalam pembentukan hemoglobin. Zat besi berperan sangat penting dalam pembentukan hemoglobin, kebutuhan zat besi dalam tubuh $65 \%$ dibutuhkan untuk pembentukan 
JOURNAL OF MIDWIFERY CARE :

VOL. 01 NO. 01, DESEMBER 2020

DOI : $10.34305 / j m c . v 1 i 1.189$
Ciptaan disebarluaskan di bawah

Lisensi Creative Commons Atribusi-

NonKomersial-Berbagi Serupa 4.0

Internasional. hemoglobin. Hemoglobin yaitu molekul protein yang mengandung zat besi dan merupakan pigmen darah yang membuat darah berwarna merah (Kusmiran, 2016).

Hasil penelitian ini juga mendukung teori bahwa kandungan besi dalam 100 gram madu terdapat kandungan besi sebesar 0,42 mg. Disamping itu juga madu mengandung enzim-enzim seperti diastase, glukosa oksidase, katalase serta vitamin A, vitamin B dan betakaroten. Selain itu juga dilengkapi mineral berupa kalium magnesium, fosfor, tembaga, mangan, natrium dan kalsium. Bahkan terdapat hidrogen peroksida yang dihasilkan oleh glukosa oksidase dan inhibin (Hudri, 2017). Pada kasus anemia ringan, madu telah terbukti mampu meningkatkan kadar hb, jika dikonsumsi selama 7 hari berturut-turut sebanyak 28 gr/hari (Islamiyah, 2017).

Penanganan anemia juga dapat dilakukan dengan pemberian buah pisang ambon. Buah pisang memiliki kandungan zat besi yang cukup tinggi sehingga cocok untuk penderita anemia. Mengkonsumsi 2 buah pisang setiap selama 7 hari dapat mengatasi kekurangan sel darah merah atau anemia. Dalam 100 gram pisang mengandung zat besi sebanyak 1,60 mg (Wardhany, 2016). Almatsier, (2015); Maesaroh \& Fauziah, (2016) mengatakan jika mengkonsumsi pisang ambon 2 kali sehari secara teratur dapat meningkatkan jumlah sel darah merah, dimakan sebaiknya pagi dan sore hari.

\section{Kesimpulan}

Pemberian madu dan pisang ambon efektif terhadap anemia karena dapat meningkatkan kadar hemoglobin mahasiswi Program Studi Diploma III Kebidanan STIKes YPIB Majalengka tahun 2020.

\section{Saran}

Bagi mahasiswi agar meningkatkan pengetahuan dan keterampilan tentang pencegahan dan penanganan anemia secara aktif dengan mengakses informasi dari berbagai media dan juga aktif mengikuti seminar mengenai masalah anemia pada remaja, sehingga mahasiswi dapat melakukan pencegahan dan penanganan secara mandiri salah satunya dengan mengkonsumsi buah pisang ambon dan madu.

\section{Daftar Pustaka}

Adji, S. (2017). Terapi dengan Madu. Penerbit Thibbia.

Almatsier, S. (2015). Prinsip Dasar Ilmu Gizi. Gramedia Pustaka Utama:

Arisman, M. (2017). Buku Ajar Ilmu Gizi: 
JOURNAL OF MIDWIFERY CARE :

VOL. 01 NO. 01, DESEMBER 2020

DOI :10.34305/jmc.v1i1.189
Ciptaan disebarluaskan di bawah

Lisensi Creative Commons Atribusi-

NonKomersial-Berbagi Serupa 4.0

Internasional.
Obesitas, Diabetes Melitus \&. Dislipidemia: Konsep, Teori dan Penanganan Aplikatif. EGC.

Briawan, D. (2017). Anemia Masalah Gizi Pada Remaja Wanita. Jakarta: EGC. diakses 20/02.

Cholifah, N., \& Wulandari, A. (2018). Aplikasi Pemberian Madu Terhadap Peningkatan Hemoglobin (HB) Pada Remaja Putri Yang Mengalami Anemia. Proceeding of The URECOL, 533-539.

Dinas Kesehatan Provinsi Jawa Barat. (2019). Derajat Kesehatan Propinsi Jawa Barat Tahun 2018. Dinas Kesehatan Propinsi Jawa Barat.

Hudri. (2017). Khasiat Madu. http://www.isdaryanto.com/khasiatmadu-lebah,

Islamiyah, N. (2017). Pengaruh Madu Terhadap Kadar Hemoglobin Remaja Putri Kelas X Yang Mengalami Anemia di SMKN 01 Mempawah Hilir. Jurnal ProNers, 3(1).

Kementerian Kesehatan RI. (2019). Profil Kesehatan Indonesia Tahun 2018. Kementerian Kesehatan RI.

Kusmiran, E. (2016). Kesehatan reproduksi remaja dan wanita. Jakarta: Salemba Medika, 21.

Maesaroh, S., \& Fauziah, A. N. (2016). Pengetahuan Remaja Putri Tentang Resiko Tindakan Aborsi Terhadap Kesehatan Dan Hukum. Jurnal Kebidanan Indonesia: Journal of Indonesia Midwifery, 9(1), 81-90.

Mahardika, N. P., \& Zuraida, R. (2016).
Vitamin C pada Pisang Ambon (Musa paradisiaca S.) dan Anemia Defisiensi Besi. Jurnal Majority, 5(4), 124-127.

Manuaba, I. B. G. (2015). Ilmu kebidanan, penyakit kandungan dan keluarga berencana. Jakarta: EGC, 15, 157.

Muslihah, P. (2017). Efektifitas Pemberian Buah Pisang Ambon (Musa Paradisiaca Var. Sapientum (L) Kunt) dengan Madu Dalam Meningkatkan Kadar Hemoglobin Mahasiswi Anemia di STIKes Bogor Husada. Naskah Publikasi STIKes Bogor Husada Tahun 2017.

Rustiani, S. (2016). Pengaruh Pemberian Buah Pisang dan Madu sebagai Peningkat Kadar Hemoglobin pada Remaja Putri yang Mengalami Anemia Defisiensi Besi di Akademi Keperawatan Pemkab Subang. Majority. 5.

Sarwono, S. W. (2015). Psikologi Remaja edisi revisi. In Jakarta: Raja Grafindo Persada. Raja Grafindo Persada.

Suprayitno. (2017). Pengaruh Pemberian Buah Pisang dan Madu terhadap Kenaikan Kadar Hemoglobin Pada Remaja Puteri Anemia di Kecamatan Cidahu Kabupaten Kuningan. 1, 5866.

Wardhany, K. H. (2016). Khasiat Tanaman Obat. Rapha Publishing.

WHO. (2018). Hipertensi dan Anemia di Dunia. http://www.who.int/

Yuni, N. E. (2015). Kelainan Darah. Yogyakarta: Nuha Medika. 